Article:

\title{
An injured Body's Encounter With Cultural Discourses
}

Young women's experiences of an injured body

by

Carina Fjelldal-Soelberg

Associate Professor, PhD

University of Nordland

Email: carina.fjelldalsoelberg@uin.no

\section{Keywords:}

Selfharm, female body, cultural discourses, "signs on the female body, qualitative interviews. 


\section{Abstract}

This article discusses the significance of gender in the encounter between an injured body and cultural discourses. When young women who self-harm present bodies that deviate from the norms for what female bodies should look like, they face sanctions. Young women who injure their own bodies are affected by social discourses about expectations for women and women's bodies, which in turn affect their gender identities. This article builds on interviews with 12 young women who injure or have injured their own bodies.

\section{Introduction}

"You are constantly faced with this bodily ideal that girls should be so pretty and clean," notes one of the informants. In current Western society, the body is in focus and the ideal body should appear perfect. This may particularly apply to women's bodies (Shilling, 2005). In the Norwegian national daily newspaper Aftenposten, Wenche Bjørnebekk writes that, "It is still girls' bodies that are subject to the highest expectations to perfection, and that are most frequently subject to assault and selftorture in the form of disordered eating and cutting" (8 January 2013). According to Shaw, women comply with cultural sanctions in order to adapt to Western beauty ideals:

What is remarkable is that it is culturally tolerable for women's bodies to be objectified and destroyed if it is inflicted by others, and when it is in the service of Western beauty ideals and men's sexual gratification. What is not culturally tolerable is for women to objectify and destroy their own bodies in ways that do not serve Western aesthetics. (Shaw, 2002:206)

When young women injure their own bodies, they invert the cultural imagery of what constitutes a beautiful female body (Shaw, 2002). The number of young people who injure their own bodies is on the increase (Sornberger et al., 2012; Wilkinson, 2012), and there is no doubt that the phenomenon "is a significant problem among the young" (Madge et al., 2011:1). A lot of research points out that bodily self-harm is more widespread among women than among men (Adler \& Adler, 2011; Moe \& Ribe, 2007; Rubæk, 2009; Sutton, 2007). Favazza and Conterio (1989) claim that the 
average self-injurer is a 28-year-old woman who started injuring herself when she was about 14, with cutting the most common form of bodily self-harm (Favazza \& Conterio, 1989). When bodily self-harm is discussed in the media, young women are often represented. This is true whether the issue is discussed in general terms or whether pop-culture celebrities with injured bodies are being presented.

Even though there is quite a bit of research that shows that injuring one's own body is most common among young women, other research claims that "the gender gap" among self-injurers is not as extensive as previously assumed (Camp et al., 2011). This relates to a gendered difference in the methods that young women and young men use when injuring their own bodies. Young women appear to use cutting to injure their bodies, while young men tend to burn or hit their own bodies (Sornberger et al., 2012). This article does not look at men's bodily self-harm, but instead focuses on young women's experiences of injuring their bodies. The main focus of the article is on the significance that the identity of being a woman plays in women's experiences of the encounter between an injured body and cultural discourses. To help address this issue, I ask the following research questions: How do young women experience having an injured body? What is the significance of the injuring of their own bodies for young women and their gender identity? This article offers descriptions, interpretations, and analyses from 12 young women, but does not represent all young women who injure their bodies. Yet at the same time, this article can say something about these women and their gendered experiences of having injured bodies. To address these important and central questions related to young women who self-injure, we will first look at what it means to injure one's own body.

\section{Bodily self-harm}

There are many concepts and definitions related to the injuring of one's own body. Internationally, self-harm, self-injury and non-suicidal self-injury (NSSI) are all in use, as research on the phenomenon is usually presented from a clinical perspective (Chandler, 2012). This article analyses bodily self-harm from a sociological perspective, which means that the behaviour is not related to internal, psychological or biological processes. Chandler (2012) uses "embodied emotion work" to describe a sociological understanding of bodily self-harm, and references Crossley ("The 
social body") with mind/body dualism. Crossley claims that the mind cannot be separated from the body, and that "we may conclude from this that sociology and dualism do not mix" (Crossley, 2001:20). In a sociological perspective, it is the body that damages and gets damaged. For example, this contrasts with a psychological perspective on bodily self-harm, which considers the mind to be what has been injured (Skårderud, 2007). Self-harm ("selvskading" in Norwegian) is the most frequently used term within this perspective, with Crossley points out that:

Human beings are embodied. We are not spirits or minds that exist inside a body. Our bodies are all there is to us. As the expression "our bodies" indicates, however, we are capable of objectifying our embodiment and constituting it as an object and possession: "my body". I am my body but I also have my body. (Crossley, 2006:140)

In other words, the social body is intersubjective, and it is available to others (Crossley, 2001, 2006). In this article, it is the social bodies of bodily self-injurers that are represented though what Shilling calls "the body as a project". This means that the body is changeable and always in process (Shilling, 2003). For bodily selfinjurers, the body is a project that is always changing as it is being injured. In accordance with the approaches to the phenomenon developed within the sociology of the body, this article uses "bodily self-harm" ("kroppsskading" in Norwegian), and primarily employs Favazza and Rosenthal's (1993) definition that "bodily self-harm is to intentionally harm one's body without having an conscious suicidal intent". Socially accepted forms of bodily harm, body modification and the harming of one's body as a form of entertainment (e.g. fakirs) are not included in this article. Furthermore, indirect bodily harm such as drug use, smoking and eating disorders are not included in the conceptualization of bodily self-harm in this article.

\section{Theoretical foundation}

The data is based on the experiences of young women who injure their own bodies, and the analysis is based on gender theories that can attend to both the gendered and embodied experiences of bodily self-harm. There are many different approaches to gender (Jegerstedt \& Mortensen 2008). This article primarily employs Butler's and 
Søndegaard's constructionist approaches, because the empirical data references understandings of gender identity, femininity and "signs on the body" related to what a female body should look like and what it represents. The use of Butler and Søndegaard strengthens the analysis of young women who injure their bodies and their experiences of gendered expectations in cultural discourses.

Butler is still considered the foremost post-structuralist gender researcher (Bols $\varnothing$, 2005), enabling new ways of thinking about gender and the body ${ }^{1}$ (Mortensen et al., 2008). Among other things, Butler inverts the distinction between sex and gender (Jegerstedt, 2008), as it has been common to think of sex as being prior to gender. In contrast, Butler argues that gender is primary:

Gender is primary, and creates the illusion of a biological sex that is more original, more natural, and which in this way constitutes a sort of inner essence that the external signs of gender mimic. In other words, sex is an effect of gender. In this way, the entire difference between sex and gender is deconstructed. (Jegerstedt, 2008:77)

According to Butler (1999), gender is not something that is, but rather something that is being done through actions. However, this does not mean that sex does not exist, but that "our conceptualization of biology is never divorced from the discursive practice that produces it as such" (Jegerstedt, 2008:79). According to Butler, gender is socially constructed from the start. The category of "girl" is a previously established unit that indicates an expectation based on discourses that are already formed (Butler, 1993). Butler claims that gender and the body do not exist prior to the discursive practices that constitute them as gender and body (Jegerstedt, 2008).

\footnotetext{
${ }^{1}$ Langås (2008) references some of the critiques of Butler (from Braidotti [2002] and Coole [2008], respectively). In part, Butler has been accused of "claiming that there is no outside of discourse, and she has been criticized for the much-discussed theory of gender performativity overlooking the materiality of the body" (Langås, 2008:1). Butler responds to this critique in Bodies That Matter, in which she extensively discusses the relationship between the material and the discursive. She argues that "the material is always already discursively incorporated into culture". Here, she also replaces the constructivist concept with the materialist concept. Crossley (2001) believes that we have a body as well as being a body, and Merleau-Ponty (1994[1945]) claims that it is through the lived body that we experience the world. This is the sociology of the body that this article follows. When bodily self-injurers harm their bodies, it is the biological body that is injured. However, bodily self-injurers do not live in a vacuum, which means that when the biological body is injured, so is the cultural body.
} 
When someone is referred to as a "girl", this creates an expectation that a girl is made into a "girl" (Søndergaard, 2007). For instance, Butler (1993) argues that when a girl is born and a statement is made that "it is a girl", an expectation of a specific type of behavior is conveyed. What this expectation entails will always vary between cultures and from a historical perspective, but will always build on pre-existing norms. Put differently, the statement "It is a girl!" is a linguistic performative that becomes significant to being a girl. This is what Butler calls "girling". "Girling" is not related to anything individual, but is a norm that must be repeated culturally and historically. Thus, the category of "girl" is not created there and then, but is an established norm (understanding) that is historically reiterated (Butler, 1993). My data shows that young women's experience of bodily self-harm is closely related to such a "girling" practice, i.e. that young women who injure their body are at the same time a process of doing gendered identity in relation to a series of established norms on "girling".

Butler claims that gender is not passive, but is actively created:

Gender is not passively scripted on the body, and neither is it determined by nature, language, the symbolic, or the overwhelming history of patriarchy. Gender is what is put on, invariably, under constraint, daily incessantly, with anxiety and pleasure, but if this continuous act is mistaken for a natural or linguistic given, power is relinquished to expand the cultural field bodily through subversive performances of various kinds. (Butler, 2003:109)

According to Butler, gender is produced through discursive practices (Jegerstedt \& Mortensen, 2008). Butler's "performativity" concept is a reformulation of Foucault's conceptualization of discourse ${ }^{2}$ (Jegerstedt, 2008). Butler claims that performativity is a repetition of a norm (or a set of norms), in which the starting point is an existing law or norm, code or contract. The performative aspects of the discourse are the reiterations of the law or the norm, code or contract (Butler, 1993). According to Butler, gender is a performative category, which means that "gender identity is

\footnotetext{
2 According to Foucault (1999), power and various forms of knowledge are closely tied together. The power that Foucault refers to is the power that different groups have when they describe, classify and diagnose other people. The discourses help shape our attitudes toward categories and concepts; there is power in the use of language (ibid.).
} 
constituted through expressions of gender" (Søndergaard, 2006:42). In other words, gender is the performative effect of specific discourses (Søndergaard, 2006). Both Butler and Søndergaard refer to a discourse constitutive force in the tension between the individual and society. Identities are never a finished product and will always be an ongoing process, and the expectations and discourses about living up to what is expected to be a girl/woman, and how an anticipated girl/women's body should look like, are challenges for young women who injure their own bodies.

Gender is something that is both within and outside of oneself, but first and foremost it is always relational (Søndergaard, 2006). "Gender exists in the structures around us, in the social order, in the cultural codes, in other actors. We mirror ourselves in all of this, as something outside of ourselves" (Søndergaard, 2006:412). Gender is performed through cultural repetition, and is not an internal force. Gender is something that everyone does through cultural reiterations. Even so, gender is not only something that is negotiated through discursive practices, but also something that is part of cultural bodies (Søndergaard, 2006). Søndergaard also looks at gender in relation to bodily signs, "by showing how gender as a category of difference is tied to signs on the body" (Berg \& Kristiansen, 2010:229). The sign on the body is not only a sign from the body to its surroundings; it is also internalized in the individual and becomes part of the individual's identity (Søndergaard, 2006). In my empirical data, the practice of bodily self-harm can be looked upon as doing with certain signs on the body, which is related to a gendered practice. Or to put it in another way, how the young women injured their bodies, how they deal with the scars as created signs on the body, or even why they chose to injure their bodies, can all be addressed not only as a "girling" practice, but also a process of dealing with the bodily signs.

The theoretical perspective presented thus far has implications for the methods used to analyse the empirical material. Analyses cannot start by cherry-picking data to fit the theory (Søndegaard, 2006); instead, the approach to the area of investigation, data collection, analysis and the presentation of the data must correspond with the theoretical perspective used (ibid.). In this way, the selection of a method and form of analysis follow from the data. 


\section{Method and analysis}

Twelve face-to-face interviews were conducted with young women between the ages of 18 and 30 who were injuring or have injured their bodies. The interviewees were recruited through health centers, outreach workers, student counseling services and a membership-based online forum. The interviews were conducted during the spring and fall of 2009, averaged 1.5 hours each. All of the interviewees had injured their bodies for several years, with a frequency that varied between weekly and daily incidents, and with some injuring themselves several times a day. Cutting was the most common method used, but interviewees also talked about burning, hitting their hands or head against the wall, stabbing themselves with sharp objects, rubbing soap into fresh wounds, picking at old wounds, hitting their arms with ropes, rubbing skin off, bloodletting, and off-road biking (with the intent of injuring their body). At the time of the interviews, five of the informants no longer injured their bodies. Three said they had stopped injuring themselves, but that they had recently had a "relapse". The final four informants were continuing to injure their bodies at the time of the interviews.

After transcription, the data was analysed as narratives. According to Kvale (1999), a narrative analysis leads to the telling of a new story based on the story from the original interview. As the researcher, I am to retell this new story in this context, but always on the basis of the experiences of those engaged in bodily self-harm. Those who bodily self-harm have first-hand knowledge about their experiences of encountering cultural discourses; hence their experiences are the ones that can provide insights about the topic. Søndegaard (2006) notes that narrative ways of knowing aim to understand and analyse the contexts that provide the meaning that people live both in and through. Narratives are reflections of one's own individual experiences, but these individual experiences must also be seen as expressions of already established cultural discourses (Järvinen, 2005). The analysis is therefore also a part of cultural discourses. The analysis is an encounter between the researcher's interpretive views and the subjective experiences of the informants, and the knowledge is something that is produced by the researcher and informants together. It is worth noting that an interview is never an interrogation of the informant's subjective experiences, but is rather a social encounter between the 
researcher and informant in which experiences are interpreted and meaning is jointly created (Järvinen, 2005).

The analysis is inspired by Søndergaard's (2006) three levels of analysis: 1) the empirical descriptions provided by the informants, 2) the coding of the data, 3) the abstraction of theoretical concepts and the analysis of the encounter between theory and the empirical material. The last of these levels of analysis, in which the interpretive coding process occurs, is what Geertz (1973) describes as a movement from "experience-near" to "experience-distant". In this part of the analysis, informants' narratives are placed within a broader signifying context, in which the codes are extracted from the empirical descriptions (Søndergaard, 2006). The codes are never disconnected from their context. Søndegaard writes about the "cultural wind directions", and it is within these directions that we must analyse "individual narratives with the complete fund of narratives in the material" in which the analysis must constantly "move back and forth between part and whole" (ibid: 60). In the last part of the analysis, the narratives from the women engaged in bodily self-harm practices are elevated from their original position and placed within a larger interpretive framework in order to illuminate the significance of gender in the encounter between an injured body and cultural discourses.

The project has been approved by the Norwegian Social Science Data Services, and has complied with research ethics guidelines.

\section{"Signs" on the female body}

Kaisa has injured her body for many years. She used razor blades to cut her arms and legs, though she mainly cuts her arms. There were periods in which she cut herself multiple times a day, while during other periods she cut herself less frequently. Kaisa has usually bandaged herself after the cutting, but she also had to go to Urgent Care for medical treatment when the cuts were too deep to treat by herself. She usually injured herself in the evening while alone in her room. For Kaisa, it was "incredibly calming to see the blood run", but the injuries left "marks" on her body. She says: 
I never wore short sleeves when I had scars (...) never. My body looked bad [laughs]. A shit-load of scars (...) and none of the other girls looked like that. I envied other girls with nice and clean arms (...) with no scars (...) my body did not fit in, it was actually just ugly [sighs]. I can understand all the looks, right (...) that they stared (...) but it was bothersome.

Kaisa talks about different ways in which she hid her body, and how she used cover stories. These were both stories she had to invent to avoid showing her body and stories she made up if her injured body became visible. In time, she started to compare her body to those of other girls, and she felt that her injured body did not measure up. She has a sense of carrying "signs", which was incompatible with being a young woman. Kaisa focuses on her body being "ugly"-it does not fulfil the requirements for what she considers to be a beautiful female body. The normal young Western woman's body should not be scarred, but young women who injure their bodies end up carrying what Søndergaard (2006) calls "signs on the body". These women carry a physical stigma (Goffman, 2000[1963]). These are "signs on the body" that Kaisa has inflicted on her body, and that she describes as "ugly". Canguilhem calls some bodies "monstrous bodies", and questions the distinction between the normal and the pathological body. "The monster is the living being of negative value" (Canguilhem, 2005:188), which means that monstrous bodies are bodies that are outside the norm. Kaisa's self-harmed body can be compared to what Canguilhem calls monstrous bodies, as she carries a body that is not socially accepted. Women who engage in bodily self-harm do not represent the Western view of what a (normal) female body should look like. According to Søndergaard (2006:97), "The surface presented should be attractive". Scars on the bodies of women who engage in bodily self-harm are incompatible with anything attractive, and are instead akin to Bakhtin's (2005) description of "the bodily grotesque". The wounded and scarred female social body communicates with the external world, and it communicates something which is not "womanly".

\section{The expectations placed upon the female body}

Maria believes that there are clear expectations for what a woman's body should look like. According to Maria, it makes a big difference whether it is a young woman or a 
young man who carries the injured body. She believes that the expectations placed on a woman's body are entirely different from those placed on a man's body, and wonders about these differences:

There is such an ideal today, that even though I sort of don't care (...), but sometimes I feel like this summer, oh God, now I have no muscles ["slapp $i$ kroppen"] and my body is so scarred, it's such a girl/women's phenomenon [laughs] (...) so the image of what I should look like (...) the expectations are incredibly high (...) and the feeling of never measuring up [sighs] (...) boys can have wounds and scars, that's cool and tough (...) like, nobody questions that (...) but for us girls, it's immediately a negative (...) and everyone looks and thinks it's awful [laughs]. Girls should be wonderful and beautiful, and when the body has so many wounds and scars, nobody thinks it's beautiful (...) and that is actually a bit strange (...) it shouldn't make a difference whether it is girls or boys who injure themselves, should it?[Laughs].

Although Maria notes that she does not care a lot about the expected body ideal, she "feels" it. She notices that she does not fit into society with an injured body, and gets looks if the scars are visible. It is obvious that Maria believes that it makes a difference as to whether it is a girl's body or boy's body that carries the scars, because the expectations for the female body are different than for the male body. According to Kraft, a marked body is noticed, and the reactions from the surroundings are often negative. "This applies not least to the marked female body" (Kraft, 2005:65). Søndergaard (2006) believes that women encounter culture ${ }^{3}$ through discourses and actions with "signs on the body". Women who bodily selfharm encounter culture with a body that carries signs, and are affected by established discourses about a normative female body. These discourses do something with how young women who injure their bodies perceive their gender identity in the encounter with culture.

\footnotetext{
3 With the use of culture Søndergaard means: "When this text speaks of culture, both codes of discursive practices and concrete practical action patterns, the last words are that organization and the routines for handlings form a given that society exists through. The youth culture is so, both in the trade context that constitutes their field, and in the discursive practices that negotiations are mediated through" (2008:40).
} 
Like Maria, June also tells about expectations for what a women's body should look like, and how to deal with it. Much of June's everyday life was focused on fitting into a world in which an injured female body has no place, and she noticed that others thought her body was "disgusting" if it became visible. June talks about how her injured body did not fit into media representations of an ideal female body:

Today, you're told by advertisements and society in general that this is what you must do to become a successful person (...) you're constantly receiving messages about the ideal body (...) girls should be pretty and clean, and you want to fulfil these expectations [eh], but not everyone does (...) my body, for example (...) I could never be a model, or in that case they would have to have airbrushed all the scars away [laughs].

June believes that there is external pressure from her surroundings for her body to correspond to society's ideal body, but her body is different. Her body does not fulfil the expectations for what a female body should look like. She believes there is too much focus on a perfect exterior, and wonders about who has "actually decided that this Barbie look is so amazingly great". June has stopped injuring her body, but the scars on her body tell a story based on many years of cutting. "Of course", June says, "when you cut and cut (...) day after day for years, of course there are scars. Many times I did it several times a day." She started to injure the inside of her arms, but after some time moved to her thighs. This was because "there was no more space on my arms; it wasn't actually possible any more (...) they were completely cut up." These scars are inscriptions on June's body, and communicate a deviant body. Søndergaard (2006) believes that women mirror themselves in culture, and that this cultural mirroring integrates culture in our bodies. Søndergaard claims that this mirroring is not something culturally strange because the culture is already established within us, and that the body becomes an arena for self-presentation in a social context (Sønderaard, 2006). The bodies of young women who bodily self-harm become a presentation of their identity, and when an injured female body does not represent the normative, this does something with the women's identities as women. Normativity is created through the reiteration of norms, or performativity (Butler, 1993). The social discourses in culture can function as interpreters of a beautiful 
female body, which in turn will affect the way that women who injure their bodies perceive their own bodies.

\section{Bodily changes}

Kaisa says that when she became pregnant, she stopped injuring her body. She says that her doctor did not think that her female body was compatible with becoming a mother:

When I became pregnant I stopped injuring myself (...) you don't do such things then (...) the doctor recommended tattoos (...) I have tattooed here (points to the outside of the other arm) (...) they cover quite well, actually (...) because it is very much in focus compared to what is underneath it (...) it was a bit weird when I was pregnant, I really felt the looks (...) if this had been a boy-a boy who had just as many scars-I don't think a doctor would ever have recommended tattoos.

Kaisa believes that the expectations placed on a young female body are higher than those placed on a young male body, and that a marked female body does not fit in: "There are demands that you do not feel that you measure up to (...) about how girls should look." There is an expectation that young women who are about to become mothers not injure their bodies or inflict wounds and scars on it. There are clear cultural expectations (or to use Butler's [1993] concept, a process of "girling") for what a young female/mother's body should look like. This is something that is already established in cultural norms. Butler points out that, "you become a girl, a gender, a gendered subject, precisely through these reiterations" (Jegerstedt, 2008:83). The body carries "signs" that are divorced from the feminine (Søndergaard, 2006). In line with what her doctor recommended for Kaisa, several informants have chosen to tattoo the scars from the bodily self-harm. In order to hide the "marks" after the bodily self-harm, they construct a "new" body. Here, a "new" body refers to the construction of something other than that which was, but it will still carry the same history. Nina has chosen to do a skin graft after years of injuring her body. She talks about skin that has been transplanted from her inner thigh to her arms, in order to cover the scars from her bodily self-harm. Nina believes that the main reason she chose a skin graft was others' reactions when the "marks" became visible. On being asked by the 
interviewer about whether the results of the skin graft were as she had expected, Nina says:

Not quite, I had hoped it would be better. But it fulfils the function I wanted, which is for it to not look like any bodily self-harm had happened there. It is more reminiscent of a skin graft as a result of a burn. A lot of people think that, and that's good enough for me.

After the skin graft, "No one has any problems with it," Nina says, with reference to her body. Nina has perhaps changed her body to a greater extent than the informants who have gotten tattoos. She has created a body that is to not carry "signs" that reference bodily self-harm. Her surroundings have also accepted these "signs"; they accept them because the scars now look more like burns than bodily self-harm. When Nina and Kaisa construct "new" bodies using large tattoos and skin grafts, they have created bodies that are socially accepted. The construction of "new" bodies also alters their identities as young women. With her "new" body, Nina can appear as a "worthy" woman. She does not need to hide her body any more, or be ashamed of it if it becomes visible.

Maria used two forms of bodily self-harm - one was socially accepted and one was not. In addition to cutting (not socially accepted), she did off-road biking (socially accepted) with the intention of injuring her body. She says:

I did it so that my shorts would cover it, I was very careful about cutting myself in ways that could be hidden (...) no one was to know about this (...) but luckily I had the biking, because when I biked I was allowed to be injured (...) nobody thought about my having injured myself, I was just thought to have been a bit unlucky and tough while on the bike.

Though Maria was biking with the intention of injuring her body, her surroundings did not see this as a form of bodily self-harm. Cutting is considered a feminine method of injuring one's body, while methods such as hitting a hand against a door or burning oneself are considered masculine methods of bodily self-harm (Camp et al., 2011). According to Butler (1993), the performative aspects of discourses lead to things 
being seen as normative. Gender is something that takes places through actions, practices and through various ways of talking about gender (Jegerstedt, 2008). Maria's narratives illustrate that bodily self-harm is at the same tame a process of doing gender. For Maria, off-road biking was not a form of bodily self-harm because such methods are rarely considered bodily self-harm. Scars on the body that can be related to cutting (feminine bodily self-harm) are therefore considered culturally deviant. In contrast, scars related to off-road biking are socially accepted marks on the body, and are considered masculine and tough. Established discourses in society relate bodily self-harm to cutting, which is seen as a feminine way of harming the body. Off-road biking is not considered part of the bodily self-harm category, so Maria could then show her body after having injured it on an extreme bike trip in the mountains. When she cut herself, she never showed her body to others, as it was not compatible with expectations of what a female body should look like.

\section{Expectations that lead to withdrawal}

\section{and the strategy to handle gendered expectations}

Kristin believes that she has always faced high expectations, and that these high expectations were due to her being a girl. She says that equivalent expectations were never placed on her brother, as: "He generally did whatever he wanted." Kristin believes that she has always been expected to look good and do well (whether at school, at home or in sports). According to Kristin, this has led her to have high expectations of herself. She says:

People around me say I expect so much of myself: I work, study and exercise a lot. I want to be just as good as everyone else, and look just as good as everyone else (...) but on the one hand, you are supposed to tell yourself that this is not necessary, while society (...) well, you feel that society otherwise expects you to handle more and look good. The societal ideal says that you should handle everything (...) So there is an ongoing conflict. Sometimes people say: [relax] and do not expect so much of yourself. But (...) easier said than done (...) and then it's the relational things, that you have to be there for others at all times (...) it's this good girl syndrome (...) I don't think boys know about this syndrome [laughs]. 
Kristin has found it difficult to handle the expectation to look good and achieve things. As Kristin notes, this "good girl" syndrome is a behaviour that she believes is expected because she is a girl/woman. According to Butler (1993:8), gender is something that is constructed through "cultural articulation". Kristin is a part of such "cultural articulations", and as a young woman she faces expectations that are difficult to meet. Some of these expectations about how to be a young woman have led Kristin to injure her body, as a type of doubleness is created through this. First, Kristin is unable to fulfil the expectations of being a "good girl" communicated through "cultural articulations". She flees the expectations placed on young women, and bodily self-harm becomes a way for her to withdraw. By bodily self-harming, she also breaks with the ideal representation of a young female (body). In any case, Kristin is unable to meet the expectations that are placed on her as a young woman.

Lisa wanted to escape the "fucking perfect world" when she injured her body. On being asked by the interviewer about why she injures herself, Lisa says:

It is a way to escape everyday life (..) you disappear into your own world when you do it (...) at least that's how it was for me [sighs] so it's like when I hurt myself it is me and the knife and that is the only world that I see right there and then (...) and it is wonderful to get away from all the external pressure and the struggle to always achieve something (...) to always look good (...) to be a successful girl (...) it sort of disappears and I go into a bubble that just (...) and then it's not me and the rest of the world, it's just me (...) and then it's like the rest of the world doesn't matter, in a way it's (...) how can I explain it (...) liberating, incredibly liberating.

The world that Lisa describes here is the only world she sees when she is injuring her body. Both Lisa and Kristin were still injuring their bodies at the time of the interviews, which shows that they relate to their bodies differently than young women who have stopped injuring their bodies. Lisa and Kristin want to get away from an everyday life in which the expectations placed on young women are too high, and they withdraw into their "bodily self-harm world". This is a world that is protected from their surroundings, where they do not need to achieve anything. It is a discreet form 
of withdrawal that is privatized, in which they can act as breachers of norms without provoking sanctions from their surroundings. As Lisa said, it was "incredibly liberating" to get away from the world in which she felt she had to represent a successful young woman. The paradox is that they flee from an everyday life with external pressures on the feminine, while at the same time engaging in an act that deviates from the feminine and creates a body that does not correspond to the signs that a female body should carry. Butler claims that norms determine and regulate how we see and perceive bodies, and that bodies must establish themselves in relation to something they are not. "This also means that deviations are produced simultaneously with the norm" (Jegerstedt, 2008:80). Young women who injure their bodies have chosen a solution that leads to permanent consequences. They become "concrete sign-carriers" (Søndergaard, 2006) in a culture where such signs deviate from the signs that young female bodies should have. Butler (1993) argues that gender difference are, "never simply a function of material difference which are not in some way both marked and performed by discursive practices" (ibid: 1). My analysis shows that young women who harm their own bodies are part of cultural discourses, and will always be affected by how discourses convey the perception on gender. When injuring their bodies, they have to face gendered attitudes and gendered expectations for how a young woman and a young woman's body should be.

One of Butler's (1999) points is that the category "woman" is not a universal one, and she emphasizes that women are different. This emerges clearly among young women who bodily self-harm and their gendered experiences. The experiences that some young women who bodily self-harm have are experiences that can be related to both gendered attitudes and to gendered expectations in cultural discourses. According to Søndegaard (2006), cultural discourses are integrated into our bodies. Gender is something that is performatively incorporated into young women who bodily self-harm. How are these women to break with this performativity? Butler $(1993,1999)$ claims that breaking performativity requires breaking with the dominant discourses. To break with the dominant discourses, young women who bodily selfharm choose different strategies. Some of the young women who bodily self-harm find that these gendered expectations are too great a burden, and they then choose a strategy in the form of a withdrawal to "their own world", where they can injure their 
bodies without being seen. Others select strategies in which they change the signs on the body (the scars) that they have accumulated during years of bodily self-harm to construct "new" bodies. These "new" bodies are bodies that are no longer socially devalued because the scars from cutting are no longer prominent, so they can then present a "worthy" young female body. Another strategy is to use a masculine form of bodily self-harm, and the paradox is that these are "bodily signs" that are socially accepted. The gendered experiences also have different meanings depending on where the women are in the bodily self-harm process, when different strategies are selected depending on whether the bodily self-harm is ongoing or not.

\section{Conclusion}

Through narratives of young women who injure their bodies, this article has illustrated the significance of gender in the encounter between an injured body and cultural discourses. At the same time, as these young women injure their own bodies it is also a process of doing gender. The Western perception of women's bodies is that they should look good (Shilling, 2005). According to Moe and Ribe, a scarred female body does not fit into current beauty ideals. "The female body is cut, but to make it prettier and cleaner, not to be marked and injured" (Moe \& Ribe, 2007:103). Young women who bodily self-harm exist in a culture and society in which they are part of established discourses. They are affected by social discourses about what is expected of a female body, and these discourses are internalized within them. Bodily self-harm leaves a female body with permanent signs that are not compatible with the current focus on the "normal" female body. Some young women who injure their bodies compare their bodies with established social discourses about what is expected of a beautiful female body. These discourses about what is perceived to be normative create guidelines for how young women with "signs on the body" perceive their own bodies. Our thoughts and behaviour are regulated by social norms, and breaching these norms leads to negative reactions from others (Goffman, 1963; Weihe, 1997).

The bodies of these young women communicate to themselves and their surroundings about their female identities. These are "signs on the body" that do not fulfill current Western discourses about what a woman's body should look like, and this is significant for young women who injure their bodies and for their gendered 
identity. They have signs on the body that deviate from other female bodies, and this leads to social sanctions. Some young women who bodily self-harm therefore choose to comply with the requirement to a normative body: They hide it or choose to change their bodily expression. They construct "new" bodies to adapt to society's normative requirement of a legitimate body, which suggests that cultural discourses become performative in young women who bodily self-harm. They mirror the gender in established cultural discourses about what is expected from young women in current society. Their injured female bodies breach established discourses about the perception and expectation to normative female bodies. Young women who engage in bodily self-harm use different strategies to adapt themselves and their "different" body in the encounter with cultural discourses. In light of this, we can ask whether social discourses about the expectations placed on young women contributes to a continuing increase in the number of young women who engage in bodily self-harm. 


\section{Bibliography:}

Adler, P. A., \& Adler, P. (2011). The tender cut. Inside the hidden world of self-injury. New York University Press.

Bakhtin, M. (2005). The grotesque image of the body and its sources. In M Fraser, \& M. Greco (Eds.), The body: A reader. London: Routledge.

Bolsø, A. (2005). Jorun Solheim og Judith Butler - en refleksjon over åpne kropper og det falliske. Tidsskrift for kjønnsforskning, 4, 05.

Berg, A. J., \& Kristiansen, T. G. (2010). Synlig forskjell - om "nyankomme innvandrere", kjønn og rasialisering. In A.-J. Berg, A. B. Flemmen, \& B. Gullikstad (Eds.), Likestilte norskheter: om kjønn og etnisitet. Oslo: Tapir.

Butler, J. (1993). Bodies that matter: On the discursive limits of "sex". New York: Routledge.

Butler, J. (1999). Gender trouble: Feminism and the subversion of identity. New York: Routledge.

Butler, J. (2003). Performative acts and gender constitution. An essay in phenomenology and feminist theory. In P. Auslander (Eds.), Performance: Critical concepts in literary and cultural studies, London: Routledge.

Camp, I. V., Desmet, M., \& Verhaeghe, P. (2011). Gender differences in non-suicidal self-injury: Are they on they on the verge of leveling off? International conference on behavior. Cognitive and psychological sciences IPCSIT, 23.

Canguilhem, G. (2005). Monstrosity and the monstrous. In M. Fraser, \& M. Greco (Eds.), The body: A reader. London: Routledge.

Chandler, A. (2012). Self-injury as Embodied Emotion Work: Managing Rationality, Emotions and Bodies. Sociology, 46, 3.

Crossley, N. (2001). The social body: Habit, identity and desire. London: Sage.

Crossley, N. (2006). Reflexive Embodiment in Contemporary Society. Maidenhead, Berkshire, England New York: Open University Press.

Dalen, M. (2004). Intervju som forskningsmetode: En kvalitativ tilnærming. Oslo: Universitetsforlag.

Favazza, A. R., \& Conterio, K. (1989). Female habitual self-mutilators. Acta Psychiatrica Scandinavica, 79, 3.

Favazza, A. R., \& Rosenthal, R. J. (1993). Diagnostic issues in self- mutilation. Hospital and Community Psychiatry, 44, 2.

Foucault, M. (1999). Diskursens orden. Tiltredelsesforelesning holdt ved Collège de France 2. desember 1970. ( Trans. Schaanning, E) Oslo: Spartacus. 
Geertz, C. (1973). The Interpretation of Cultures/Selected Essays. Harper Torchbooks. New York: Basic Books.

Goffman, E. (1963). Behavior in public places: Notes on the social organization of gatherings. New York: Free Press.

Goffman, E. (2000[1963]). Stigma: om afvigerens sociale identitet. Gyldendals Samfundsbibliotek.

-Jegerstedt, K. (2008). Judith Butler. In E. Mortensen, C. Egeland, R. Gressgård, C. Holst, K. Jegerstedt, S. Rosland, \& K. Sampson (Eds.), Kjønnsteori. Oslo: Gyldendal akademisk.

Jegerstedt, K., \& Mortensen, E. (2008). Hva er kjønn? Ulike tilnærmingsmåter. In E. Mortensen, C. Egeland, R. Gressgård, C. Holst, K. Jegerstedt, S. Rosland, \& K. Sampson (Eds.), Kjønnsteori. Oslo: Gyldendal akademisk.

Järvinen, M. (2005). Interview i en interaktionistisk begrepsramme. Kvalitative Metoder I Et Interaktionistisk Perspektiv. M. Järvinen, \& M.-M. Nanna (Eds.), Hans Reitzels Forlag.

Kraft, S.-E. (2005). Den Ville Kroppen: Tatovering, piercing og smerteritualer i dag. Oslo: Pax.

Kvale, S. (1999). Det Kvalitative Forskningsintervju. Oslo: Ad Notam Gyldendal AS.

Langås, U. (2008). Kjønnets materialitet eller materialitetens kjønn? En diskusjon av Judith Butlers Bodies that matter. Tidsskrift for kjønnsforskning, 4.

Madge, N. ${ }^{1}$, Hawton, K., McMahon, E. M., Corcoran, P. L., De Leo. D., Wilde, E. J., Fekete, S., . . Arensman, E. (2011). Psychological characteristics, stressful life events and deliberate self-harm: Findings from the Child \& Adolescent Self-harm in Europe (CASE) Study. European Child and Adolescent Psychiatry, 20 (10).

Merleau-Ponty, M. (2004[1945]). Kroppens Fenomenologi. Oslo: Pax.

Moe, A., \& Ribe, K. (2007). Selvskadingens dynamikk. Oslo: Universitetsforlag.

Mortensen, E., Egeland, C., Gressgård, R., Holst, C., Jegerstedt, K., Rosland, S., \& Sampson, K. (2008). Kjønnsteori. Oslo: Gyldendal akademisk.

Rubæk, L. (2009). Selvskadens psykologi. Virum: Dansk psykologisk forlag.

Schiefloe, P. M. (2003). Mennesker Og Samfunn/Innføring I Sosiologisk Forståelse. Bergen: Fagbokforlaget.

Shaw, S. N. (2002). "Shifting Conversations on Girls' and Women's Self-Injury: An Analysis of the Clinical Literature in Historical Context." Feminism and Psychology 12.2: 191-219. 
Shilling, C. (2003). The Body and Social Theory (2.ed.). London: Sage Publications Ltd.

Shilling, C. (2005). The body in culture, technology and society. London: Sage Publications Ltd.

Skårderud, F. (2007). Uro: En reise i det moderne selvet. Oslo: Aschehoug.

Sornberger, M. J., Heath, N. L., Toste, J. R., \& McLouth, R. (2012). Non-suicidal selfinjury and gender: Patterns of prevalence, methods, and locations among adolescents. Suicide and Life-Threatening Behavior, 42, 3.

Sutton, J. (2007). Healing the hurt within: Understand self-injury and self-harm, and heal the emotional wounds. Oxford: Howtobooks.

Søndergaard, D. M. (2006). Tegnet på kroppen: Køn: Koder og konstruktioner blandt unge voksne i Akademia. København: Museum Tusculanums Forlag.

Søndergaard, D. M. (2007). Feministiske tænkere: En tekstsamling. København: Hans Reitzels forlag.

Weihe, H.-J.W. (1997). Relasjonsarbeid og kommunikasjon. Oslo: Tano Aschehoug.

Wilkinson, P. (2012). Non-suicidal self-injury. European Child and Adolescent Psychiatry, 1-5.

\section{Other sources}

-Aftenposten 08.01.2013. 